ISSN 2078-6441. Вісник Львівського університету. Серія географічна. 2013. Випуск 44. С. 333-343. Visnyk of the Lviv University. Series Geography. 2013. Issue 44. P. 333-343.

$631.445 .9(477.83)$

\author{
льг ов \\ ввівський н ціон льний університет імені в н \\ вул. . орошенк, 41, 79000, м. ввів, кр їн
}

ведено результ ти досліджень в лового хімічного скл ду грунтів янсько- ністерської височини. озглянуто особливості вмісту оксидів у грунт х т грунтотворних пород х. ро н лізов но зміни, які відбув ються в одній з н йконсерв тивніших субст нцій грунтів ун слідок нтропогенного використ ння.

лючові слов : сірі лісові грунти, темно-сірі опідзолені грунти, чорноземи опідзолені, в ловий хімічний скл д, оксиди, молярні відношення, вилуговув ння, конституційн вод .

ловий скл д грунту - це сукупність хімічних елементів т їхнє кількісне співвідношення у грунтовій м сі [7, с. 30]. ослідження елемент рного скл ду грунту виконують 3 допомогою комплексу визн чень, які н зив ють в ловим хімічним н лізом.

ловий хімічний н ліз ( $\quad$ ) д є змогу одерж ти інформ цію про в ловий хімічних скл д мінер льної ч стини грунту і порівняти його зі скл дом незмінної грунтотворної породи. ке порівняння допом г є виявити відносне т бсолютне збільшення бо зменшення кількості речовини в об'ємі горизонтів ун слідок грунтотворного процесу. рім того, порівняльний н ліз вмісту хімічних елементів у грунтовому профілі д є змогу визн чити х р ктер змін в лового хімічного ст ну, спричинених інтенсивним сільськогоспод рським використ нням грунтів упродовж трив лого ч су.

скільки мінер льн ч стин грунту вирізняється зн чною консерв тивністю, то н підст ві результ тів в лового профільного н лізу можн стверджув ти про тенденцію розвитку елемент рних грунтових процесів, які відбув ються в профілі грунту, причому як реліктових, т к і суч сних $[2,6,8]$.

ля н лізу д них в лового хімічного скл ду грунту використовують різні перер хунки і коефіцієнти, які д ють змогу оцінити генетичні процеси, безпосередньо пов’яз ні з бсолютною і відносною зміною хімічного скл ду мінер льної ч стини грунтів в спекті їхньої генези й нтропогенного впливу. ихідною формою перер хунку д них в лового хімічного н лізу є перер хунок н сухий грунт (висушений 3 темпер тури $105^{\circ}$ ).

оловним з вд нням генетичного вивчення мінер льної ч стини твердої ф зи грунту є з'ясув ння змін ії хімічного скл ду під впливом грунтотворного процесу, тому зіст влення одерж них д них, вир жених у відсотк х від м си сухого грунту, не д $є$ істинного уявлення про зміни мінер льної ч стини грунту, оскільки н кількості кожного оксиду позн ч ється вміст гумусу і хімічно зв'яз ної води в кожному генетичному горизонті. ідт к зн чення гумусу і хімічно зв'яз ної води необхідно вилучити зі скл ду гумусу. е можливо у вип дку перер хунку д них, вир жених

(C) ов ., 2013 
у відсотк х від м си сухого грунту, у величини, вир жені у відсотк х від мінер льної м си грунту, тобто у відсотк х від прож реного грунту $[2,6]$.

о 30-х років ст. грунтів широко використовув ли грунтозн вці. н чну ув гу приділяли збир нню д них про елемент рний скл д грунтів, в гові відсотки кожного $з$ елементів вир ж ли через їхні оксиди. підст ві цих д них робили висновки про винесення чи кумуляцію елементів, що були головними для оцінки н пряму процесів грунтоутворення [5]. 40-х рок х ст. учені зн чну ув гу приділяли визн ченню молекулярних співвідношень i, як н слідок, робили висновки про кумуляцію т винесення елементів у грунті. дн к тр ктув ння результ тів були досить примітивними: будь-яке зменшення відсоткового вмісту елемент порівняно 3 його вмістом у м теринській породі вв ж ли озн кою ктивного винесення, збільшення - ктивного н копичення.

1944 p. . олинов з зн ч в, що в ловий хімічний н ліз був необхідним поч тковим ет пом усіх досліджень і визн ч в н прям под льших н лізів і визн чень, які могли б привести до вирішення в жливих пит нь генезису грунтів [9].

н чну ув гу вивченню грунтів т розробці методики н лізу приділяв . оде. чений з пропонув в порівнюв ти вихідний м тері л і продукти звітрюв ння порід (тобто грунт) у перер хунку н безкв рцовий грунт, що, н його думку, зумовлено інертністю кв рцу. дн к ці положення не були методично обгрунтов ні й не н були з стосув ння. . оде, використовуючи як елемент-свідок кв рц, дет льно розробив методику р ціон льного н лізу дослідження . роте його "p ціон льний” н ліз м є суттєві недоліки, оскільки поширюється н специфічні умови грунтоутворення, в яких відбув ються процеси повного розкл ду всіх мінер льних з'єдн нь, 3 винятком кв рцу, у тому числі й глинистих мінер лів. о-друге, цей метод не д $є$ змоги робити висновки про природу і джерело н явних у грунті вторинних мінер лів, які можуть міститися у вихідному м тері лі, виникнути в процесі грунтоутворення і бути переміщеними з однієї ч стини профілю в іншу [11].

ні в лового хімічного скл ду сірих, темно-сірих грунтів і чорноземів опідзолених н ведені в пр цях . убилін і . олотов , . хтирцев і . етиніної, . ерн pдер i . одлін, . ндрущенк $[6,7,8,9,10]$. роте в літер турних джерел х недост тньо інформ ційної б зи щодо в лового хімічного скл ду грунтів янськоністерської височини.

и досліджув ли в ловий елемент рний скл д сірих, темно-сірих грунтів т чорноземів опідзолених, зокрем , викон ли профільний н ліз в лового хімічного скл ду, обгрунтув ли з лежність елемент рного скл ду грунтів від вл стивостей грунтотворної породи, виявили зміни в лового хімічного скл ду грунтів під впливом сільськогоспод рської діяльності.

икон но в ловий хімічний н ліз і визн чено відсотковий вміст оксидів $\mathrm{SiO}_{2}$, $\mathrm{Al}_{2} \mathrm{O}_{3}, \mathrm{Fe}_{2} \mathrm{O}_{3}, \mathrm{CaO}, \mathrm{MgO}, \mathrm{K}_{2} \mathrm{O}, \mathrm{Na}_{2} \mathrm{O}, \mathrm{P}_{2} \mathrm{O}_{5}, \mathrm{SO}_{3}$ від м си сухого грунту, т кож втр ти від прож рюв ння.

трим ні результ ти перер хов но н прож рений грунт, обчислено молярні співвідношення оксидів. ні в лового хімічного н лізу опр цьов но 3 з г льноприйнятою методикою . ндрушкіної [2].

езульт ти вивчення в лового хімічного скл ду сірих, темно-сірих т чорноземів опідзолених н ведено у т бл. 1-3. езульт ти в лового хімічного н лізу, вир жені у відсотк х від м си прож реного грунту, коли елімінов но вплив орг нічної речовини н відносний вміст оксидів, з свідчують, що особливістю в лового хімічного скл ду сірих 
лісових грунтів янсько- ністерської височини є високий вміст оксиду силіцію $\left(\mathrm{SiO}_{2}\right)$ в меж х усієї ч стини генетичного профілю цих грунтів (т бл. 1).

ловий хімічний скл д грунтів янсько- ністерської височини, $\%$ від м си прож реного грунту

\begin{tabular}{|c|c|c|c|c|c|c|c|c|c|c|c|c|c|}
\hline $\begin{array}{r}\text { енетичні } \\
\text { горизонти }\end{array}$ & $\mid \begin{array}{c}\text { либин } \\
\text { відбору } \\
\text { зр } \\
\text { сків, } \\
\text { см }\end{array}$ & $\begin{array}{c}\text { ігроскопі- } \\
\text { чн волог , } \\
\%\end{array}$ & $\begin{array}{c}\text { тр ти } \\
\text { від } \\
\text { прож - } \\
\text { рюв ння, } \\
\%\end{array}$ & $\mathrm{SiO}_{2}$ & $\mathrm{Al}_{2} \mathrm{O}_{3}$ & $\mathrm{Fe}_{2} \mathrm{O}_{3}$ & $\mathrm{CaO}$ & $\mathrm{MgO}$ & $\mathrm{CO}_{2}$ & $\mathrm{~K}_{2} \mathrm{O}$ & $\mathrm{Na}_{2} \mathrm{O}$ & $\mathrm{P}_{2} \mathrm{O}_{5}$ & $\mathrm{SO}_{3}$ \\
\hline \multicolumn{14}{|c|}{ озріз 13. ірий опідзолений глеюв тий легкосуглинковий (переліг) } \\
\hline e+Ihop g] & $4-14$ & 1,26 & 4,47 & 82,77 & 9,09 & 3,19 & 0,75 & 0,53 & $\mathrm{H} / \mathrm{B}$ & 2,30 & 1,09 & 0,14 & 0,13 \\
\hline Ih $\mathrm{gl}$ & $34-42$ & 1,27 & 3,66 & 80,20 & 11,11 & 4,03 & 0,75 & 0,21 & $\mathrm{H} / \mathrm{B}$ & 2,32 & 19 &, 11 & 0,09 \\
\hline Ie gl & $45-55$ & 1,27 & 3,12 & 79,13 & 11,36 & 4,26 & 0,90 & 0,64 & $\mathrm{H} / \mathrm{B}$ & 2,27 & 1,17 &, 15 & 0,12 \\
\hline \multicolumn{14}{|c|}{ озріз 14. ірий опідзолений глеюв тий легкосуглинковий (ліс) } \\
\hline E gl & $3-35$ & 1,18 & 4,08 & 84,45 & 8,86 & 2,34 & 0,45 & 0,32 & $\mathrm{H} / \mathrm{B}$ & 2,26 & 1,09 &, 09 & 0,15 \\
\hline Ih gl & $34-49$ & 3 & 2,67 & 84,64 & 8,69 & 2,50 & 0,29 & 0,42 & $\mathrm{H} / \mathrm{B}$ & 16 & ,04 & 08 &, 19 \\
\hline Pgl & $150-160$ & 1,20 & 2,65 & 80,23 & 11,38 & 3,56 & 0,74 & 0,42 & $\mathrm{H} / \mathrm{B}$ & 2,32 & 1,19 & 0,08 & 0,08 \\
\hline \multicolumn{14}{|c|}{ озріз 12. емно-сірий опідзолений глеюв тий легкосуглинковий (ліс) } \\
\hline $\mathrm{e}$ & $3-20$ & 1,25 & 6,04 & 83,76 & 8,80 & 2,59 & 0,46 & 0,76 & $\mathrm{H} / \mathrm{B}$ & 2,29 & 1,14 & 0,08 & 0,12 \\
\hline e & $20-46$ & 1,31 & 4,07 & 84,20 & 8,61 & 2,53 & 0,59 & 0,42 & H/B & 2,33 & 1,15 &, 08 & 0,07 \\
\hline $\mathrm{Hi}$ & $50-60$ & 1,21 & 3,14 & 82,17 & 9,51 & 3,13 & 0,88 & 0,63 & $\mathrm{H} / \mathrm{B}$ & 2,37 & 1,15 & 0,07 & 0,08 \\
\hline \multicolumn{14}{|c|}{ озріз 8. емно-сірий опідзолений глеюв тий легкосуглинковий (рілля) } \\
\hline eop & $0-26$ & 1,20 & 5,12 & 83,70 & 9,09 & 2,56 & 0,91 & 0,32 & $\mathrm{H} / \mathrm{B}$ & 2,11 & 1,12 & 0,11 & 0,09 \\
\hline еп/ор & $26-44$ & 1,26 & 4,83 & 83,11 & 9,52 & 2,56 & 0,90 & 0,54 & $\mathrm{H} / \mathrm{B}$ & 2,00 & 1,08 & 0,15 & 0,15 \\
\hline Higl & $46-56$ & 7 & 3,87 & 83,22 & 9,40 & 2,73 & 0,88 & 0,53 & $\mathrm{H} / \mathrm{B}$ & 1,95 & 1,05 & 0,07 & 0,16 \\
\hline Pgl & $128-160$ & 1,33 & 2,86 & 81,78 & 10,63 & 3,37 & 0,89 & 0,64 & $\mathrm{H} / \mathrm{B}$ & 2,20 & 1,17 & 0,06 & 0,08 \\
\hline \multicolumn{14}{|c|}{ озріз 3. орнозем опідзолений легкосуглинковий глеюв тий (ліс) } \\
\hline e & $2-20$ & 1,38 & 4,47 & 85,11 & 8,50 & 2,08 & 0,43 & 0,53 & $\mathrm{H} / \mathrm{B}$ & 2,00 & 1,08 &, 10 & 0,18 \\
\hline $\mathrm{e}$ & $20-41$ & 1,37 & 3,23 & 85,56 & 8,41 & 2,06 & 0,53 & 0,32 & $\mathrm{H} / \mathrm{B}$ & 1,92 & 1,01 & 08 & 0,12 \\
\hline pie & $43-53$ & 1,31 & 3,02 & 83,37 & 9,32 & 2,86 & 0,65 & 0,62 & $\mathrm{H} / \mathrm{B}$ & 1,95 & 1,06 & 0,07 & 0,13 \\
\hline \multicolumn{14}{|c|}{ озріз 1. орнозем опідзолений легкосуглинковий глеюв тий (рілля) } \\
\hline op & $0-29$ & 1,17 & 4,57 & 84,29 & 8,42 & 2,69 & 0,87 & 0,52 & $\mathrm{H} / \mathrm{B}$ & 1,93 & 1,03 & 0,20 & 0,07 \\
\hline п/оp & $29-42$ & 1,27 & 4,17 & 83,64 & 8,90 & 2,49 & 0,87 & 0,84 & $\mathrm{H} / \mathrm{B}$ & 1,94 & 1,00 & 0,15 & 0,18 \\
\hline pie & $45-55$ & 1,27 & 3,95 & 84,78 & 8,42 & 2,48 & 0,87 & 0,53 & $\mathrm{H} / \mathrm{B}$ & 1,91 & 1,02 & 0,08 & 0,21 \\
\hline Pgl & $160-170$ & 1,32 & 2,22 & 81,22 & 9,99 & 3,30 & 0,72 & 0,94 & $\mathrm{H} / \mathrm{B}$ & 2,35 & 1,21 & 0,06 & 0,20 \\
\hline
\end{tabular}

окрем , у цілинних сірих лісових грунт х вміст $\mathrm{SiO}_{2}$ у горизонті $\mathrm{E}_{\mathrm{gl}}$ ст новить $84,45 \%$, м ксим льний вміст оксиду силіцію в горизонті Ih gl - 84,64 \%, у н прямі до грунтотворної породи його вміст зменшується і ст новить 80,23\%. кий перерозподіл оксиду иліцію вниз по профілю $є$ н слідком його відносного н копичення через втр ту більш мобільних елементів. окультурених сірих лісових грунт х вміст $\mathrm{SiO}_{2}$ колив ється в меж х 79,1-82,77\%, м ксим льн кількість $\mathrm{SiO}_{2} є$ з поверхні у горизонті e+Ihop ${ }_{\mathrm{gl}}$, униз по профілю вміст оксиду силіцію зменшується.

ipi лісові грунти вирізняються високим вмістом півтор оксидів. Г лом у профільному розподілі всіх півтор оксидів простежується т к з кономірність: верхня ч стин профілю збіднен $\mathrm{H} \quad \mathrm{R}_{2} \mathrm{O}_{3}$ порівняно з ілюві льним горизонтом і м теринською породою, де сконцентров н їхня м ксим льн кількість.

скл ді півтор оксидів перев ж $є \mathrm{Al}_{2} \mathrm{O}_{3}$, вміст якого в сірих лісових грунт х природних біоценозів т гроценозів ст новить, відповідно, 8,86-11,38 \% т 9,09-11,36\% (див. т бл. 1). 
профільному розподілі оксиду феруму в сірих лісових грунт х янськоністерської височини простежено з кономірність до збільшення $\mathrm{Fe}_{2} \mathrm{O}_{3}$ в н прямі до грунтотворної породи. прикл д, вміст $\mathrm{Fe}_{2} \mathrm{O}_{3}$ під природними біоценоз ми ст новить 2,34-3,56\%, під гроценоз ми - 3,19-4,26\%.

кий розподіл хімічних елементів х р ктерний для грунтів, у яких розвив ється комплекс елюві льно-ілюві льних (опідзолення, лесив ж). езульт том підзолистого процесу грунтотворення є руйнув ння у верхніх горизонт х грунтів первинних і вторинних мінер лів (крім кв рцу) і винесення продуктів руйнув ння (з звич й, $\mathrm{Al}_{2} \mathrm{O}_{3} \mathrm{i}$ $\mathrm{Fe}_{2} \mathrm{O}_{3}$ ) у нижню ч стину профілю. $\mathrm{p}$ зі розвитку процесу лесив жу відбув ється мех нічне винесення мулув тих ч стинок, без їхної деструкції, p зом із ними - i півтор оксидів з верхніх ч стин грунту з под льшою їхньою кумуляцією в ілюві льному горизонті.

міст оксидів м гнію $(\mathrm{MgO})$ і к льцію ( ) у в ловому хімічному скл ді сірих лісових грунтів незн чний, н них прип д є до $1,5 \%$. низ по профілю вміст цих оксидів дещо зрост $є$. скл ді мінер льної ч стини твердої ф зи грунту більше міститься оксидів к лію і н трію, ніж к льцію і м гнію.

іст вивши хімічний скл д грунтотворних порід з елемент рним скл дом генетичних горизонтів сірих лісових грунтів, ми виявили зб г чення верхніх горизонтів грунту силіцієм і їхнє збіднення півтор оксид ми порівняно з м теринською породою.

и розр ховув ли молярні співвідношення різних оксидів, які свідч ть про неоднорідність хімічного скл ду мінер льної ч стини грунту і диференці цію профілю сірих лісових грунтів янсько- ністерської височини.

бчислені співвідношення $\mathrm{SiO}_{2}: \mathrm{Al}_{2} \mathrm{O}_{3}, \mathrm{SiO}_{2}: \mathrm{Fe}_{2} \mathrm{O}_{3}, \quad \mathrm{SiO}_{2}: \mathrm{P}_{2} \mathrm{O}_{5}, \mathrm{Al}_{2} \mathrm{O}_{3}: \mathrm{Fe}_{2} \mathrm{O}_{3}$ д ють змогу визн чити відносні втр ти бо н копичення окремих оксидів у генетичних горизонт х ун слідок руйнув ння і переміщення по профілю мінер лів, продуктів їхнього руйнув ння під впливом комплексу елюві льно-ілюві льних , т кож виявити природу цих процесів.

олярні співвідношення $\mathrm{SiO}_{2}: \mathrm{Al}_{2} \mathrm{O}_{3}, \mathrm{SiO}_{2}: \mathrm{Fe}_{2} \mathrm{O}_{3}$ свідч ть про відносну втр ту оксидів люмінію і феруму у верхній ч стині профілю сірих лісових грунтів у товщі 0-35 см, оскільки їхні зн чення в гумусово-елюві льних горизонт х н йширші: 16,20 і $1,31 \%$ у горизонті $\mathrm{E}_{\mathrm{gl}}$ під лісом т 15,48 і 69,19\% під перелогом. ілюві льному горизонті досліджув них грунтів під лісом молярні співвідношення дещо розширюються і ст новлять $16,56 \%$ для $\mathrm{SiO}_{2}: \mathrm{Al}_{2} \mathrm{O}_{3}$ i $56,01 \%$ для $\mathrm{SiO}_{2}: \mathrm{Fe}_{2} \mathrm{O}_{3}$. окультурених сірих лісових грунт х простежується тенденція до звуження пок зників молярних співвідношень порівняно 3 гумусово-елюві льним горизонтом. окрем, співвідношення $\mathrm{SiO}_{2}: \mathrm{Al}_{2} \mathrm{O}_{3}$ ст новить $12,27 \%, \quad \mathrm{SiO}_{2}: \mathrm{Fe}_{2} \mathrm{O}_{3}-53,0 \%$. йбільше оксид ми люмінію $\mathrm{i}$ феруму зб г чен м теринськ пород, в якій молярне співвідношення $\mathrm{SiO}_{2}: \mathrm{Al}_{2} \mathrm{O}_{3}$ т $\mathrm{SiO}_{2}: \mathrm{Fe}_{2} \mathrm{O}_{3}$ ст новить 11,99 і 50,22 \%, відповідно (див. т бл. 2).

рім молярних співвідношень, для півтор оксидів розр хов но молярні співвідношення для лужноземельних мет лів у грунт х: ${ }_{2}+\mathrm{Na}_{2} \mathrm{O}: \mathrm{Al}_{2} \mathrm{O}_{3}$ і $\mathrm{CaO}+\mathrm{MgO}: \mathrm{Al}_{2} \mathrm{O}_{3}$. підст ві їхніх зн чень обчислено ф ктор вилуговув ння, з пропонов ний . єнні [12].

ктор вилуговув ння розр ховують 3 співвідношенням суми оксидів у певному горизонті до суми цих же оксидів у м теринській породі. сірих лісових грунт х простежується кумуляція ${ }^{+}{ }^{+} \mathrm{Na}^{+}$щодо $\mathrm{Al}_{2} \mathrm{O}_{3}$, про що свідчить ф ктор вилуговув ння пон д 1. йбільш кумуляція ${ }^{+}{ }_{\mathrm{T}} \mathrm{Na}^{+} €$ в ілюві льному сл бкоелювійов ному горизонті окультурених сірих лісових грунтів, де пок зник вилуговув ння ст новить 1,77. 
ок зники диференці ції профілю темно-сірих опідзолених грунтів янсько- н ністерської височини

\begin{tabular}{|c|c|c|c|c|c|c|c|c|c|c|}
\hline \multirow[b]{2}{*}{ 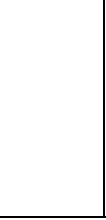 } & \multirow[b]{2}{*}{ 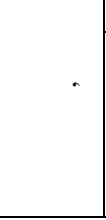 } & \multicolumn{9}{|c|}{ олярні співвідношення } \\
\hline & & $\begin{array}{l}\mathrm{SiO}_{2} \\
\mathrm{Al}_{2} \mathrm{O}_{3}\end{array}$ & $\begin{array}{c}\mathrm{SiO}_{2} \\
\mathrm{Fe}_{2} \mathrm{O}_{3}\end{array}$ & $\begin{array}{l}\mathrm{SiO}_{2} \\
\mathrm{P}_{2} \mathrm{O}_{3}\end{array}$ & $\begin{array}{l}\mathrm{Al}_{2} \mathrm{O}_{3} \\
\mathrm{Fe}_{2} \mathrm{O}_{3}\end{array}$ & $\frac{\mathrm{MgO}+\mathrm{CaO}+\mathrm{Na}_{2}}{\mathrm{Al}_{2} \mathrm{O}_{3}}=\underline{\mathrm{O}+\mathrm{K}_{2}} 2 \underline{\mathrm{O}}$ & 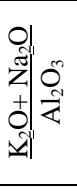 & 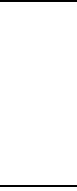 & 㗊 & 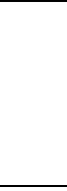 \\
\hline \multicolumn{11}{|c|}{ озріз 13. ірий опідзолений глеюв тий легкосуглинковий (переліг) } \\
\hline e+lhop gl & $4-14$ & 15,48 & 69,19 & 1399,21 & 4,47 & 0,77 & 0,47 & 1,21 & 0,30 & 1,47 \\
\hline Ih gl & $34-42$ & 12,27 & 53,07 & 1725,52 & 4,32 & 0,57 & 0,40 & 1,03 & 0,17 & 0,81 \\
\hline Ie gl & $45-55$ & 11,82 & 49,03 & 1248,50 & 4,19 & 0,67 & 0,69 & 1,77 & 0,29 & 1,38 \\
\hline \multicolumn{11}{|c|}{ озріз 14. ірий опідзолений глеюв тий легкосуглинковий (ліс) } \\
\hline E gl & $3-35$ & 16,20 & 70,60 & 2220,72 & 5,94 & 0,66 & 0,48 & 1,23 & 0,18 & 0,86 \\
\hline Ih gl & $34-49$ & 16,56 & 56,01 & 2303,93 & 5,43 & 0,65 & 0,47 & 1,21 & 0,18 & 0,86 \\
\hline $\mathrm{Pgl}$ & $150-160$ & 11,99 & 50,22 & 2373,47 & 5,01 & 0,61 & 0,39 & & 0,21 & \\
\hline \multicolumn{11}{|c|}{ озріз 8. емно-сірий опідзолений глеюв тий легкосуглинковий (рілля) } \\
\hline eop & $0-26$ & 14,60 & 81,31 & 1679,47 & 5,57 & 0,71 & 0,45 & 1,10 & 0,25 & 0,89 \\
\hline eп/op & $26-44$ & 13,87 & 80,89 & 1225,14 & 5,83 & 0,71 & 0,41 & 1,00 & 0,29 & 1,04 \\
\hline Higl & $46-56$ & 14,15 & 76,44 & 2645,93 & 5,40 & 0,71 & 0,41 & 1,00 & 0,29 & 1,04 \\
\hline Pgl & $128-160$ & 12,30 & 60,86 & 3033,67 & 4,94 & 0,69 & 0,41 & & 0,28 & \\
\hline \multicolumn{11}{|c|}{ озріз 12. емно-сірий опідзолений глеюв тий легкосуглинковий (ліс) } \\
\hline e & $3-20$ & 16,17 & 86,34 & 2605,36 & 5,34 & 0,81 & 0,50 & 1,06 & 0,31 & 1,10 \\
\hline $\mathrm{e}$ & $20-46$ & 16,62 & 88,59 & 2348,92 & 5,33 & 0,76 & 0,51 & 1,09 & 0,25 & 0,89 \\
\hline $\mathrm{i}$ & 50-60 & 14,68 & 69,95 & 2651,68 & 4,76 & 0,81 & 0,47 & 1,15 & 0,33 & 1,17 \\
\hline \multicolumn{11}{|c|}{ озріз 3. орнозем опідзолений легкосуглинковий глеюв тий (ліс) } \\
\hline $\mathrm{e}$ & $2-20$ & 17,02 & 109,12 & 2014,27 & 6,41 & 0,72 & 0,46 & 1,02 & 0,25 & 0,67 \\
\hline $\mathrm{e}$ & $20-41$ & 17,30 & 110,76 & 2531,15 & 6,4 & 0,66 & 0,45 & 1,00 & 0,21 & 0,57 \\
\hline pie & $43-53$ & 15,21 & 77,73 & 2818,7 & 5,11 & 0,71 & 0,41 & 0,91 & 0,30 & 0,8 \\
\hline \multicolumn{11}{|c|}{ озріз 1. орнозем опідзолений легкосуглинковий глеюв тий (рілля) } \\
\hline op & $0-29$ & 17,04 & 83,56 & 997,43 & 4,90 & 0,80 & 0,45 & 1,00 & 0,35 & 0,95 \\
\hline п/ор & $29-42$ & 15,98 & 89,57 & 1319,63 & 5,61 & 0,84 & 0,42 & 0,93 & 0,42 & 1,14 \\
\hline pie & $45-55$ & 17,12 & 91,16 & 2508,08 & 5,33 & 0,80 & 0,45 & 1,00 & 0,35 & 0,95 \\
\hline Pgl & $160-170$ & 13,82 & 65,63 & 3203,68 & 4,75 & 0,83 & 0,45 & & 0,37 & \\
\hline
\end{tabular}

н чення ф ктор вилуговув ння для оксидів ${ }^{2+} \mathrm{i} \mathrm{g}^{2+}$ стосовно $\mathrm{Al}_{2} \mathrm{O}_{3}$ у сірих лісових грунт х під лісом є м лим $(<1)$. і пок зники свідч ть про вилуговув ння к льцію і м гнію з верхніх горизонтів і їхню кумуляцію в нижніх горизонт х. одо окультурених сірих лісових грунтів, то ф ктор вилуговув ння у верхньому орному горизонті ст новить 1,43 , отже, відбув ється процес н копичення оксидів ${ }^{2+} \mathrm{i} \mathrm{g}^{2+}$.

т бл. 3 н ведено результ ти розр хунків вмісту конституційної води і коефіцієнт зміни силік тної ч стини у досліджув них грунт х. міст конституційної води обчислюв ли з різницею між втр тою від прож рюв ння і відсотковим вмістом гумусу т перер хув ли у молярну кількість. співвідношенням вмісту молярної кількості конституційної води в тому чи іншому горизонті грунту до ії вмісту в грунтотворній породі розр хув ли пок зник зміни силік тної ч стини. онституційн вод входить іон ми - до скл ду молекули речовини. ей вид хімічно зв'яз ної води є компонентом глинистих мінер лів, які утворюються в процесі грунтотворення і ст новлять основну м су глинистої фр кції. міст конституційної води мінім льний в ілюві льних горизонт х. окрем , н йменший вміст конституційної води у сірих лісових грунт х під 
природними біоценоз ми у горизонті Ihgl, де він ст новить $1,85 \%$, під гроценоз ми у горизонті Iegl - 2,84\%. скільки хімічно зв'яз н вод входить до скл ду мулув тих і колоїдних ч стинок грунту, то т кий розподіл у грунтовому профілі відобр ж є винесення їх з гумусово- кумулятивного горизонту і н копичення в ілюві льному горизонті.

оефіцієнт зміни силік тної ч стини в цілинних сірих лісових грунт х янськоністерської височини колив ється в меж х 0,83-1,03\%, в окультурених відмін х цей пок зник зн чно вищий і ст новить 1,27-1,54\%. чевидно, помітне зрост ння вмісту конституційної води і зн чення зміни силік тної ч стини в орному горизонті окультурених грунтів порівняно з цілинними зумовлене тим, що вн слідок обробітку, періодичних і різкіших змін вологих і посушливих періодів ктивізуються процеси крист ліз ції мінер лів 3 уч стю півтор оксидів $\mathrm{Al}_{2} \mathrm{O}_{3}$ і $\mathrm{Fe}_{2} \mathrm{O}_{3}$, що супроводжується вивільненням конституційної води. е свідчить про посилення внутрішньогрунтового звітрюв ння в орних горизонт х окультурених відмін грунтів порівняно з цілинними н лог ми.

в ловому хімічному скл ді темно-сірих опідзолених грунтів по всіх генетичних горизонт х серед оксидів перев ж є оксид силіцію $\left(\mathrm{SiO}_{2}\right)$, вміст якого в гумусовоелюві льному горизонті е ст новить 83,76-84,20 \% і з глибиною поступово зменшується (див. т бл. 1). івтор оксиди $\mathrm{Al}_{2} \mathrm{O}_{3}$ і $\mathrm{Fe}_{2} \mathrm{O}_{3}$ у горизонті е ст новлять 8,61-8,80\% т 2,53-2,59\%, відповідно, з глибиною їхній вміст зрост є, досяг ючи м ксимуму в м теринській породі gl. міст невисокий і ст новить 0,46-0,59\% у горизонті е, зберіг ючи тенденцію до зрост ння з глибиною. одо $\mathrm{MgO}$, то м ксим льний їхній вміст з поверхні у горизонті е $(0,76 \%)$, н йнижчий - н глибині 26-46 см $(0,42 \%)$, нижче, у н прямі до грунтотворної породи, їхня кількість з глибиною зрост є і в породі ст новить $0,63 \%$.

окультурених грунт х простежується тенденція до незн чного зменшення вмісту оксидів силіцію в меж х генетичних горизонтів порівняно з грунт ми під лісовою рослинністю (див. т бл. 1). е пояснюють ктивнішим підзолистим процесом під лісовою рослинністю, тоді як під культурними грофон ми підзолистий процес сповільнюється і н був є розвитку дерновий процес грунтоутворення. більшення вмісту $\mathrm{Al}_{2} \mathrm{O}_{3}$ i $\mathrm{Fe}_{2} \mathrm{O}_{3}$ зумовлене, очевидно, посиленням окисних процесів і зменшенням інтенсивності промивного водного режиму. орівняно різке зрост ння вмісту оксидів к льцію можн пояснити тр нсформ цією скл ду орг нічної речовини, що н дходить у грунт через зміну рослинного покриву, внесенням мінер льних добрив і меліор нтів, посл бленням промивного водного режиму.

втр ти верхніми генетичними горизонт ми $\mathrm{Al}_{2} \mathrm{O}_{3}$ i $\mathrm{Fe}_{2} \mathrm{O}_{3}$ т $3 б$ г чення ними ілюві льного горизонту свідч ть молярні співвідношення $\mathrm{SiO}_{2}: \mathrm{Al}_{2} \mathrm{O}_{3}, \quad \mathrm{SiO}_{2}: \mathrm{Fe}_{2} \mathrm{O}_{3}$, $\mathrm{SiO}_{2}: \mathrm{Al}_{2} \mathrm{O}_{3}$, оскільки їхні зн чення в гумусово-елюві льному горизонті - н йширші, в ілюві льному - н йвужчі в меж х профілю. піввідношення $\mathrm{SiO}_{2}: \mathrm{Al}_{2} \mathrm{O}_{3}, \mathrm{SiO}_{2}: \mathrm{Fe}_{2} \mathrm{O}_{3}$, $\mathrm{SiO}_{2}:{ }_{2} \mathrm{O}_{5}$ у генетичному горизонті е темно-сірих опідзолених грунтів янськоністерської височини ст новлять, відповідно, 16,17, 86,34 і $2605,36 \%$. гумусовоілюві льному горизонті цілинних грунтів молярні відношення ст новлять 14,68 \% для $\mathrm{SiO}_{2}: \mathrm{Al}_{2} \mathrm{O}_{3}$ i 69,95 \%, для $\mathrm{SiO}_{2}: \mathrm{Fe}_{2} \mathrm{O}_{3}-2651,68 \%$ (див. т бл. 2).

темно-сірих опідзолених грунт х під ріллею простежується тенденція до звуження молярних співвідношень між силіцієм і півтор оксид ми порівняно з цілинними н лог ми. вуження цих співвідношень свідчить про менші втр ти півтор оксидів верхніми горизонт ми. ті, відповідно, про посл блення процесу опідзолення. 
ля х р ктеристики інтенсивності процесів мігр ції к льцію і м гнію, т кож лужноземельних мет лів к лію і н трію з стосов но ф ктор вилуговув ння, 3 пропонов ний . єнні. трим ні результ ти свідч ть про невелику кумуляцію ${ }^{2+} \mathrm{Mg}^{2+}$ стосовно $\mathrm{Al}_{2} \mathrm{O}_{3}$ в меж х грунтового профілю грунтів під лісовою рослинністю і їхніх окультурених н логів. осяг ючи н йбільших зн чень у верхньому гумусовоелюві льному горизонті - 1,06-1,09, з глибиною зн чення ф ктор вилуговув ння звужується (див. т бл. 2).

окультурених відмін х темно-сірих опідзолених грунтів з фіксов но тенденцію до звуження ф ктор вилуговув ння порівняно з цілинними н лог ми. ричиною цього є вимив ння к тіонів к льцію і м гнію дрен жними вод ми із верхніх горизонтів грунту і збільшення їхнього вмісту в нижній ч стині грунтового профілю. цьому р зі не треб відкид ти впливу нтропогенного чинник, пов'яз ного з внесенням мінер льних добрив і меліор нтів, зміною х р ктеру рослинності т водного режиму грунтів.

результ т ми досліджень, вміст конституційної води у профілі темно-сірих опідзолених грунтів зменшується вниз по профілю (див. т бл. 3). йвищі зн чення коефіцієнт зміни силік тної ч стини з фіксов ні в гумусово-елюві льному горизонті, де вміст конституційної води ст новить 2,26-3,34 \% під природними біоценоз ми т 2,45-2,48 \% під гроценоз ми. йнижчі зн чення коефіцієнт зміни силік тної ч стини - у гумусово-ілюві льному горизонті i, які під лісом ст новлять 1,92 \% т під ріллею - 0,86 \%. оефіцієнт зміни силік тної ч стини в цілинних темно-сірих опідзолених грунт х у профілі колив ється в меж х 0,67-0,82, в окультурених відмін х $0,86-0,97$.

орноземи опідзолені серед усіх досліджув них грунтів янсько- ністерської височини м ють н йвищий вміст оксиду силіцію.

окрем , вміст $\mathrm{SiO}_{2}$ у гумусово-елюві льному горизонті колив ється в меж х 85,11-85,56 \%, поступово знижуючись униз по профілю. кий перерозподіл пояснюЮть відносним н коПиченням оксиду силіцію вн слідок втр ти більш мобільних елементів. окультурених відмін х вміст $\mathrm{SiO}_{2}$ у горизонті ор ст новить 84,29\%, у підорному горизонті п/ор - 83,64\%. профільному розподілі оксиду силіцію виявлено н логічну тенденцію як і в цілинних чорнозем х опідзолених.

орноземи опідзолені м ють порівняно невисокий вміст півтор оксидів. ерхня ч стин профілю, передусім гумусовий елюві льний горизонт, збіднений $\mathrm{H}_{2} \mathrm{R}_{2} \mathrm{O}_{3}$ (10,47-10,58 \%) порівняно з горизонтом ріе т грунтотворною породою. ксим льн кількість півтор оксидів зосереджен в м теринській породі й ст новить 13,29 \%.

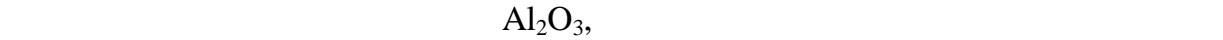
природними біоценоз ми т гробіоценоз ми ст новить, відповідно, 8,41-9,32 \% т 8,42-9,99\%

міст оксидів к льцію і м гнію у чорнозем х опідзолених ст новить у середньому 0,9-1,5 \%. ідносний вміст сполук 2 т $\mathrm{Na}_{2} \mathrm{O} \in$ вищим. окрем , цілинні чорноземи опідзолені містять 1,92-2,0\% ${ }_{2} \quad$ т 1,01-1,08 \% $\mathrm{Na}_{2} \mathrm{O}, \quad$ в окультурені відміни $1,91-2,35 \% \quad 2$ і $1,00-1,21 \% \mathrm{Na}_{2} \mathrm{O}$.

р ктерною особливістю профільного розподілу елемент рного скл ду мінер льної ч стини досліджув них грунтів є збільшення з глибиною вмісту півтор оксидів люмінію і феруму. н логічний перерозподіл по профілю х р ктерний для силік тного к льцію ( $)$, к лію ( 2 ) т м гнію (MgO). 
міст конституційної води в темно-сірих опідзолених грунт х янсько- ністерської височини

\begin{tabular}{|c|c|c|c|c|c|c|c|}
\hline 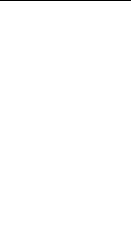 & 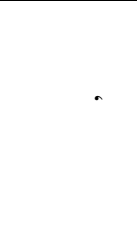 & 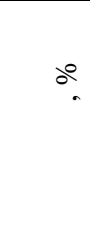 & 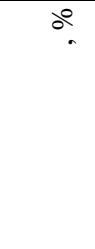 & $\begin{array}{l}\delta^{0} \\
0 \\
\sum_{\lambda}^{0}\end{array}$ & 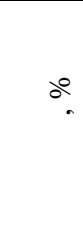 & 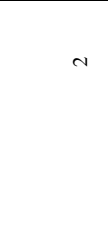 & 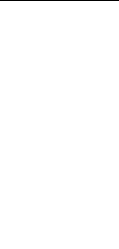 \\
\hline \multicolumn{8}{|c|}{ озріз 14.} \\
\hline E gl & $3-35$ & 1,18 & 4,08 & 1,79 & 2,29 & 127,22 & 1,03 \\
\hline Ih gl & $34-49$ & 1,13 & 2,67 & 0,82 & 1,85 & 102,78 & 0,83 \\
\hline Pgl & $150-160$ & 1,20 & 2,65 & 0,26 & 2,23 & 123,89 & - \\
\hline \multicolumn{8}{|c|}{ озріз 13. ірий опідзолений глеюв тий легкосуглинковий (переліг) } \\
\hline e+Ihop gl & $4-14$ & 1,26 & 4,47 & 1,55 & 2,92 & 162,22 & 1,31 \\
\hline Ih gl & $34-42$ & 1,27 & 3,66 & 0,43 & 3,23 & 190,56 & 1,54 \\
\hline Ie $\mathrm{gl}$ & $45-55$ & 1,27 & 3,12 & 0,28 & 2,84 & 157,78 & 1,27 \\
\hline \multicolumn{8}{|c|}{ озріз 8. емно-сірий опідзолений глеюв тий легкосуглинковий (рілля) } \\
\hline eop & $0-26$ & 1,73 & 5,12 & 2,50 & 2,62 & 145,56 & 0,92 \\
\hline еп/op & $26-44$ & 1,82 & 4,83 & 2,06 & 2,77 & 153,8 & 0,97 \\
\hline Higl & $46-56$ & 2,03 & 3,87 & 1,42 & 2,45 & 136,11 & 0,86 \\
\hline $\mathrm{Pgl}$ & $128-160$ & 2,84 & 2,86 & - & 2,86 & 158,89 & 1 \\
\hline \multicolumn{8}{|c|}{ озріз 12. емно-сірий опідзолений глеюв тий легкосуглинковий (ліс) } \\
\hline $\mathrm{e}$ & $3-20$ & 1,55 & 5,04 & 1,70 & 3,34 & 94,44 & 0,59 \\
\hline $\mathrm{e}$ & $20-46$ & 1,46 & 4,07 & 1,81 & 2,26 & 125,56 & 0,79 \\
\hline $\mathrm{i}$ & $50-60$ & 1,62 & 3,14 & 1,20 & 1,92 & 106,67 & 0,67 \\
\hline \multicolumn{8}{|c|}{ озріз 3. орнозем опідзолений легкосуглинковий глеюв тий (ліс) } \\
\hline $\mathrm{e}$ & $2-20$ & 1,38 & 4,47 & 2,00 & 2,47 & 137,22 & 1,11 \\
\hline $\mathrm{e}$ & $20-41$ & 1,37 & 3,23 & 1,01 & 2,22 & 123,33 & 1 \\
\hline pie & $43-53$ & 1,31 & 3,02 & 0,80 & 2,22 & 123,33 & 1 \\
\hline \multicolumn{8}{|c|}{ озріз 1. орнозем опідзолений легкосуглинковий глеюв тий (рілля) } \\
\hline op & $0-29$ & 1,17 & 4,57 & 2,43 & 2,14 & 118,89 & 0,96 \\
\hline п/оp & $29-42$ & 1,27 & 4,17 & 1,96 & 2,21 & 122,78 & 0,99 \\
\hline pie & $45-55$ & 1,27 & 3,95 & 1,52 & 2,43 & 135,00 & 1,09 \\
\hline Pgl & $160-170$ & 1,32 & 2,22 & - & 2,22 & 123,33 & - \\
\hline
\end{tabular}

ро збіднення верхніх горизонтів грунтів $\mathrm{Al}_{2} \mathrm{O}_{3}$ i $\mathrm{Fe}_{2} \mathrm{O}_{3}$ т $3 б$ г чення ними нижніх горизонтів можн судити 3 пок зник ми молярних співвідношень $\mathrm{SiO}_{2}: \mathrm{Al}_{2} \mathrm{O}_{3}$ т $\mathrm{SiO}_{2}: \mathrm{Fe}_{2} \mathrm{O}_{3}$, оскільки вони в гумусово- кумулятивному горизонті $є$ н йширшими, вниз по профілю звужуються. п піввідношення $\mathrm{SiO}_{2}: \mathrm{Al}_{2} \mathrm{O}_{3}, \mathrm{SiO}_{2}: \mathrm{Fe}_{2} \mathrm{O}_{3}$ у генетичному горизонті е чорноземів опідзолених ст новить, відповідно, 17,02 і 109,12 під лісом, 17,04 і 83,56\% н ріллі. гумусовому перехідному ілюві льно-елювійов ному горизонті молярні співвідношення ст новлять $15,21 \%$ для $\mathrm{SiO}_{2}: \mathrm{Al}_{2} \mathrm{O}_{3}$ i 77,73 \% для $\mathrm{SiO}_{2}: \mathrm{Fe}_{2} \mathrm{O}_{3}$, в окультурених відмін х - 17,12 і 91,16\%, відповідно, для $\mathrm{SiO}_{2}: \mathrm{Al}_{2} \mathrm{O}_{3}$ т $\mathrm{SiO}_{2}: \mathrm{Fe}_{2} \mathrm{O}_{3}$.

скільки співвідношення $\mathrm{SiO}_{2}: \mathrm{Al}_{2} \mathrm{O}_{3}, \mathrm{SiO}_{2}: \mathrm{Fe}_{2} \mathrm{O}_{3}$ т $\mathrm{SiO}_{2}: \mathrm{R}_{2} \mathrm{O}_{3}$ є ді гностичним критерієм процесу опідзолення, то можн зроби висновок, що в окультурених чорнозем х опідзолених процес опідзолення є сл бший, ніж під природними біоценоз ми. 
ктор вилуговув ння для оксидів к лію і н трію колив ється у вузьких меж х (0,91-1,02). н чення ф ктор вилуговув ння для i $\mathrm{Mg}$ стосовно $\mathrm{Al}_{2} \mathrm{O}_{3}$ під лісом $\epsilon$ менше 1, що свідчить про вимив ння цих сполук униз по профілю. окультурених відмін х грунтів цей пок зник близький до 1, отже втр т цих сполук пр ктично нем є.

Йвищий вміст конституційної води т коефіцієнт зміни силік тної ч стини є в гумусово-елюві льному горизонті й ст новить, відповідно, 2,47 т 1,11\%. низ по профілю зн чення цих пок зників незмінне і ст новить 2,22 \% т 1 . одо окультурених відмін чорноземів опідзолених, то для них х р ктерне збільшення вмісту конституційної води і коефіцієнт зміни силік тної ч стини вниз по профілю. міст конституційної води в гумусово-елюві льному горизонті в ріює в меж х 2,14-2,21 \%, досяг ючи м ксим льного зн чення у горизонті ріе $(2,43 \%)$. оефіцієнт зміни силік тної ч стини у горизонті е $\epsilon>1(0,96-0,99)$, у горизонті рie - 1,09, що свідчить про вилуговув ння оксидів і Mg з гумусово-елюві льного горизонту й кумуляцію в горизонті ріе (коефіцієнт зміни силік тної ч стини - 1,09).

тже, в ловий хімічний скл д грунту, як сп дков вл стивість від м теринської породи, тр нсформується під дією елемент рних грунтових процесів. міни елемент рного скл ду горизонтів грунту можн виявити, порівнявши його 3 в ловим хімічним скл дом м теринської породи. визн ченими змін ми можн говорити про інтенсивність, х р ктер і спрямов ність грунтових процесів.

інер льн ч стин сірих, темно-сірих грунтів т чорноземів опідзолених 3 скл дом пр ктично двокомпонентн : вон скл д ється 3 кремнезему т півтор оксидів. езн чн ч стин прип д є н оксиди к лію, н трію, к льцію, м гнію, фосфору. кий елементний скл д досліджув ні грунти усп дкув ли від м теринської породи.

ксиди з зменшенням їхнього відносного вмісту можн розт шув ти в т кий ряд: $\mathrm{SiO}_{2} \rightarrow \mathrm{Al}_{2} \mathrm{O}_{3} \rightarrow \mathrm{Fe}_{2} \mathrm{O}_{3} \rightarrow \mathrm{K}_{2} \mathrm{O} \rightarrow \mathrm{Na}_{2} \mathrm{O} \rightarrow \mathrm{CaO} \rightarrow \mathrm{MgO} \rightarrow \mathrm{P}_{2} \mathrm{O}_{5}$

підст ві порівняння в лового хімічного скл ду окультурених і цілинних чорноземів опідзолених можн зробити висновок про консерв тивність мінер льної ч стини грунту. езульт ти в лового хімічного н лізу сірих, темно-сірих лісових грунтів т чорноземів опідзолених під природними біоценоз ми (ліс) т гроценоз ми (рілля, переліг) не виявили зн чних відмінностей.

допомогою зіст влення хімічного скл ду грунтотворних порід 3 елементним скл дом генетичних горизонтів досліджув них грунтів виявлено зб г чення верхніх горизонтів грунту силіцієм і їхнє збіднення півтор оксид ми порівняно з м теринською породою.

н ліз д них в лового хімічного скл ду з свідчив, що для окультурених сірих $\mathrm{i}$ темно-сірих лісових грунтів х р ктерні вужчі зн чення відношень $\mathrm{SiO}_{2}: \mathrm{Al}_{2} \mathrm{O}_{3}$, $\mathrm{SiO}_{2}: \mathrm{Fe}_{2} \mathrm{O}_{3}$ т $\mathrm{SiO}_{2}: \mathrm{R}_{2} \mathrm{O}_{3}$, ніж для цілинних н логів. им грунт м вл стиві менші втр ти $\mathrm{Al}_{2} \mathrm{O}_{3} \mathrm{~T} \quad \mathrm{Fe}_{2} \mathrm{O}_{3}$ у верхніх горизонт х. чорнозем х опідзолених простежено протилежну тенденцію.

\section{СПИСОК ВИКОРИСТАНОЇ ЛІТЕРАТУРИ}

1. ндрущенко . . рунти з хідних обл стей . . $1 /$. . ндрущенко. ьвів; убляни : ільн кр їн , 1970. - 295 с.

2. ринушкин . . уководство по химическому н лизу почв / . . ринушкин .. : зд-во оск. ун-т , 1970. - . 260-269. 
3. хтырцев. . зменение серых лесных почв реднерусской лесостепи в процессе сельскохозяйственного освоения / . . хтырцев, . . етин . - р нск : зд-во ордов. гос. ун-т , 1969. - 164 с.

4. хтыриев . . зменения гумусного состояния лесостепных и степных черноземов под кург н ми и при длительной р сп шке / . . хтирцев, . . хтырцев // очвоведение. - 2002. - № 2. - . 140-149.

5. оул . енезис и кл ссифик ция почв / . оул, . оул, . к- рекен. - . : рогрес, 1977. -416 с.

6. якин . . етодическое пособие для чтения результ тов химических н лизов почв / . . якин , . . ринушкин . - . : зд-во оск. ун-т , 1979. - 62 с.

7. рлов . . имия почв / . . рлов. - . : зд-во оск. ун-т , 1985. - 376 с.

8. олузеров . . методике количественной оценки процесс почвообр зов ния н основе химического н лиз / . . олузеров // очвоведение. - 1970. - № 9. . 26-33.

9. олынов . . ловой почвенный н лиз и его толков ние / . . олынов // очвоведение. - 1944. - № 10. - . 482-490.

10. очвы / [ . . ерн рдер, . . олдин, . . мбур, . . корин ]. иев; рьков : осизд т. сельхоз. лит-ры, 1951. - 320 с.

11. оде . . истем методов исследов ния в почвоведении / . . оде. - овосибирск : ук , 1971.-92 с.

12. Jenny $H$. Behavior of potassium and sodium during the process of soil formations / H. Jenny // Missouri Agric. Exp. Sta. Res. Bull. - 1931. - № 162. - P. 42-52.

\author{
m ття:н дійшл до ред кцї̈ 10.04.2013 \\ доопр цьов н 10.05 .2013 \\ прийнят до друку 17.06.2013
}

\title{
GROSS CHEMICAL COMPOSITION OF SOIL OF SIAN-DNIESTER UPLAND
}

\section{Olha Sova}

Ivan Franko National University of Lviv, P. Doroshenko St., 41, UA - 79000, Lviv, Ukraine

The results of studies of the gross chemical composition of soil of Sian-Dniester upland were given. Features of oxide content in soils and soil-forming rocks were considered. The changes that take place in one of the most conservative substances of soil due to anthropogenic use are analyzed.

Key words: grey forest soils, dark grey podzolic soils, podzolized chernozems, gross chemical composition, oxides molar ratio, leaching, constitutional water. 


\section{Льг}

ввовский н цион льный университет имени в н

ул. . орошенко, 41, 79000, г. ьвов, кр ин

риведено результ ты исследов ния в лового химического сост в почв нсконестровской возвышенности. ссмотрено особенности содерж ния оксидов в почв х и почвообр зов тельных пород х. ро н лизиров но изменения, которые происходят в одной из с мых консерв тивных субст нций почв вследствие нтропогенного использов ния.

лючевые слов : серые лесные почвы, темно-серые оподзоленные почвы, черноземы оподзоленные, в ловой химический сост в, оксиды, молярные отношения, выщел чив ние, конституционн я вод . 